\title{
Countermeasures for Implementing Strategy for Orderly Real Estate Destocking
}

\author{
Yong Ma, Qingjun Meng, Yuting Liu \\ Business School in Hohai University, Nanjing, China \\ Email: 595930926@qq.com
}

Received 1 August 2016; accepted 26 August 2016; published 29 August 2016

Copyright (C) 2016 by authors and Scientific Research Publishing Inc.

This work is licensed under the Creative Commons Attribution International License (CC BY). http://creativecommons.org/licenses/by/4.0/

c) (i) Open Access

\begin{abstract}
Under the background of slow economic development speed in China, orderly real estate destocking is related to national economy and people's livelihood. Orderly destocking faces some problems, such as heavy pressure over orderly destocking and severe regional and structural differentiation. According to present situation, it is necessary to take control of supply and demand of real estate properly and implement differentiated regulation and control policy and other measures to implement the strategy of real estate destocking.
\end{abstract}

\section{Keywords}

Real Estate, Destocking, Economic Structure, Structural Reform of Supply Side

\section{Introduction}

China's economic growth has entered the " 6 era". For example, $6.9 \%$ expected growth means to say goodbye to the rapid economic growth driven by capital formation and simple element investment under the background of "three stages stack", and to carry out the "excessive industrial capacity reduction, destocking, de-leveraging, cost reduction and short board making" structural reform of supply-side means the starting of economic nature "soft landing" under the "new normal" of economic growth quality caused by total factor productivity [1]. In the first half of 2016, China's economy has achieved certain results in employment, price and income. However, it also faces some problems. Firstly, the international environment is complex and severe, the world economy recovers slowly, the trade continues to slump, and uncertain factors in economic operation are increasing, such as the De European referendum in Britain. Secondly, China is in an important stage of structural adjustment, transformation and upgrading, but the growth rate of private investment and industrial investment continues to fall, foreign trade and import/export continues to slump, and differentiation of economic structure is more serious.

On the central finance and economics leading group meeting in November 2015, the general secretary Xi 
Jinping emphasized on expanding the total demand; making efforts to strengthen the structural reform of supply side and to improve the quality and efficiency of the supply system; enhancing the momentum of sustained economic growth and promoting China's social productivity to achieve the overall leap. On the central economic working conference in December 2015, destocking of real estate was included in the five major tasks of economic work in 2016. After that, a series of policies to stable real estate market and promote the destocking of real estate had been released one after another, such as reducing the down payment proportion of housing loans, reducing housing transaction taxes and fees. On the politburo meeting in April 2016, the destocking of real estate was positioned as "ordered digestion".

Yan Yuejin (2016) believes that orderly digestion of real estate inventory should ensure the stable release of inventory, avoid the situation that price changes radically and falls immediately if the policy tightens. Zhang Dawei (2016) said that orderly digestion of real estate inventory would change previous policy orientation, namely changing from general stimulus to make policies by cities, refine the destocking task according to the different characteristics of different cities. It is estimated that the policy focus for future destocking will concentrate on the third-tier and lower-tier cities that have larger pressure on destocking, and the possibility for the first-tier and second-tier cities to issue stimulus policies will reduce. Guo Yi (2016) believes that although the digestion of real estate inventory has been steadily advancing, but the property inventory differentiation pattern is gradually intensifying. Part cites have begun to make up the inventory, while the inventory in third-tier and lower-tier cities are still difficult to deal with [2]. Therefore, this paper is aimed to find the fundamental causes through the facts analysis of hindering the process in orderly real estate destocking, and combining with the actual situation of our country, to put forward countermeasures to implement strategy for orderly real estate destocking.

\section{Problems in Orderly Real Estate Destocking}

\subsection{Heavy Pressure over Orderly Destocking}

The real estate stock across the country is mainly comprised of three parts, namely the built commercial residential building area for sale (formed supply quantity), under-construction unsold area (under construction) and supply quantity formed by land area to develop in the future (potential supply quantity) [3]. According to Annual Report on Development of Housing Market in China 2015-2016, it reveals that the total stock of commercial houses had stood at about 4 billion $\cdot \mathrm{m}^{2}$ by the end of 2015, in which the area for sale namely ready house stock was about 426 million $\cdot \mathrm{m}^{2}$. The absorption period was 23 months; speaking of property under construction, the area under construction for sale was 3.57 billion $\cdot \mathrm{m}^{2}$, whose absorption period was 4.5 years. In case that the housing supply is increased by $10 \%$ on this basis, the supply of commercial houses in China in the five years to come will reach 8.82 billion $\cdot \mathrm{m}^{2}$ [4]. By the end of Jun., 2016, the area of nationwide commercial houses for sale had reached 714.16 million $\cdot \mathrm{m}^{2}$, reducing by 7.53 million $\cdot \mathrm{m}^{2}$ than that in May and 21 million $\cdot \mathrm{m}^{2}$ in March. In spite of decline to a certain extent, the absolute scale is still high. Due to the serious imbalance in market structure segmentation, the pressure over commercial market stock is heavier. There are such problems as high vacancy rate, low rental and hard absorption in commercial market. The pressure over stock is overall heavier than that over commercial housing market. Chinese real estate market faces exceptionally heavy pressure over destocking. More, if the problem about destocking of Chinese real estate market is not solved, the pressure over Chinese economic decline cannot be adjusted easily.

\subsection{Insufficient Quantity Demand Arising from the Change in Total Population and Structure}

Speaking of the basic element that is not favorable for real estate destocking, the change trend of China's total population and structure might result into demand contraction [5]. Population structure is a main factor driving the prosperity of real estate market in the past years. However, it is about to be changing. The major population purchasing houses in China (population aged between 25 and 49) will reach the peak in 2017 but will begin to decline. Meanwhile, a large quantity of new apartments exceeding the quantity demand will also be put into market. The house-purchase population size will be reduced in large scale. The descent velocity of urban house-purchase population will far surpass the rural counterparts at the same time. However, it is far impossible for the rural counterparts to purchase expense apartments. The house-purchase population size in China began 
declining from 2015. The real estate market experienced the change in demand structure. Actually, the constructional shortage might occur to the purchasing power. The population aged from 25 to 49 in China will reach the peak value of 568 million next year but will be reduced to 543 million in 2020 and below 500 million in 2025 . The data in 2010 shall be 547 million [6]. The reduction in potential purchasing power will be a huge challenge in the development real estate. The two-child policy was officially issued by the state on Jan., 1, 2016 so as to cope with this challenge to a certain extent.

\subsection{Irrational Method for Orderly Real Estate Destocking}

The progress in destocking was made in first half of 2016. By the end of Apr., 2016, the area of commercial houses for sale across the county was $727 \mathrm{million} \cdot \mathrm{m}^{2}$ and it had already been reducing for two consecutive months. The increase this time is mainly the result brought by the hot real estate market in first-tier and some second-tier cities. Wherein, there is no lack of fixed demand, but the financial leverage plays a significant role. Further, the financial businesses including easy bank loan, down payment and crowd funding also play a role. However, high leverage means high risk. The increase of leverage will directly bring about exaggerated "siphon effect" of real estate market. Besides, the fund will be centralized in first and second-tier cities. As a result, the difficulty in destocking in third and fourth-tier cities is more severe and the housing price in hotspot cities will roar dramatically. Even, the financial leverage will not only expedite real estate market bubble and increase the financial risk but also lead to real economic "decline" and "hollowing". The reason that the central government proposes the destocking policy is to realize stable and sound industrial development while activate the stock of real estate industry. However, in case that the institution or investors have speculative house purchasing behavior, the rational allocation of real estate stock will be wasted due to the short-term speculative transaction. Besides, the housing price will be increased again, thus the financial bubble of real estate will be derived [7]. House is for living. Such positioning should not be deviated. The destocking should be realized through "people’s urbanization" rather than leveraging up.

\subsection{Severe Regional and Structural Differentiation of Real Estate}

The real estate market warming at the present is mainly driven by the first-tier cities like Beijing and Shanghai and their surrounding cities as well as some second-tier cities including Nanjing. The real estate market in the third and fourth-tier cities basically doesn't rebound. There is short supply of real estate in places with high housing price but the real estate in places with low housing price is sluggish. The absorption period of real estate in hot cities such as: Suzhou, Nanjing, Hefei and Shanghai is about 4 years while that in third and fourth-tier cities including Dalian, Quanzhou and Yantai usually exceeds 25 years. Thus, destocking should have been done without delay. The regional and structural differentiation of real estate is still the major problem. From Jan. to Apr., 2016, the speed increasing ratio of sold area of commercial houses in key cities is higher by $10 \%$ than that in non-key cities. In late Apr., the area of commercial houses for sale in key cities was $272 \mathrm{million} \cdot \mathrm{m}^{2}$, reducing by 6 million $\cdot \mathrm{m}^{2}$ than that in Mar, 3.97 million $\cdot \mathrm{m}^{2}$ in last year. The area for sale in non-key cities was 455 million $\cdot \mathrm{m}^{2}$, reducing by 2.26 million $\cdot \mathrm{m}^{2}$ than that in Mar but increasing by 12.33 million $\cdot \mathrm{m}^{2}$ than that in last year. The pressure over destocking is still heavy [8]. The stock is even positively replenished in some hot first and second-tier cities however, the destocking of real estate market in third and fourth-tier cities remains to be realized. What's more, the regional difference is also apparent. According to the data of Zhongyuan Real Estate, it shows that the difference among eastern, middle and western regions is very obvious. It is weakest in the western region. For example, the real estate development investment in former three quarters is only increased by $2.1 \%$ while the residential investment is reduced by $0.3 \%$ [9].

\section{Countermeasures for Strategies over Implementing Orderly Real Estate Destocking}

\subsection{Controlling Supply and Demand of Real Estate Properly}

Destocking shall be mainly made from two aspects, including supply and demand. Under current situation, it is necessary strictly control the supply of real estate besides vigorously increasing the demand for real estate. It is necessary adopt subtraction for supply side to reduce new house development scale in cities with high stock. The abandoned unfinished projects should be reduced through forms such as merge \& acquisition [10]. Particu- 
larly, it is necessary to reduce the supply of top-grade villa real estate. However, it is necessary control the supply of improvement and livable houses according to the local situation to keep rational quantity. In some regions with large area for sale, it is necessary to strictly control the approval for real estate and adjust the purpose of the land for real estate that is not developed yet, the construction for infrastructure and public service facilities and increase the attraction and cost performance ratio of real estate to motivate potential demand population to buy. To firmly control the "water gate" of land supply, it is necessary to strictly execute national land resource [2015] document No. 37 and adjust the purpose of the land for real estate that is not developed yet, rehandle the procedure for land use, reevaluate the land amount and the projects with social realistic demand including pension and culture in cities and counties with obvious more area of real estate for sale and construction area [3].

\subsection{Raising Labor Productivity and Technical Innovation}

The period of " $13^{\text {th }}$ Five-year Plan" is the one when the dividend of Chinese population is gradually lost. The population age structure we benefited from over the past 30 years in China is now changing from the role of expediting economic growth to that of dragging economic development. The advantageous labor-intensive industry faces the problem about upgrading of capital and technology-intensive industries at the arrival of Lewis Turning-point. The latent economic growth rate is decreasing gradually. Now, China is at the stage of accelerated development. Due to the reduction of economic growth rate, people's income will slow down. It is not favorable urbanization of rural population. Besides, the consumption of real estate will also be reduced. To cope with this problem, at the period of accelerated development, the dividend can be extended and productivity can be increased through measures such as: releasing the limit of urban household registration, equalizing fundamental public services, carrying forward the process of social security institution reform, extending the age for retirement, increasing female labor participation rate, developing advantages over human resources to encourage $\mathrm{R} \& \mathrm{D}$ and innovation and releasing labor forces in non-market redundant employment in state-owned enterprises and institutions [11]. It is necessary to encourage enterprises, scientific research institutions and universities to achieve innovations and expedite the process of transformation of scientific research achievements into practical productivity during upgrading of technology-intensive industries.

\subsection{Increasing the Demand for Real Estate during the Reforms Such as Urbanization}

It is one of main ways to obtain urban household registration to purchase house in city in China. The urbanization of rural population could bring about robust demand for real estate market, which is one of main methods for realizing stable and sound endogenous power of real estate, expediting urbanization rate of registered population and expedite real estate destocking. Therefore, it is necessary exert great efforts to implement household registration system reform, build sound supporting systems such as finance \& tax and land for urban migrant workers. It is the strategic emphasis to abide by new-type urbanization by taking "people's urbanization" as the core characteristic to transform the mode and adjust structure of China's economy. Effective destocking could be realized by associating e-commerce and real estate according to the development of current situation. The problem about real estate destocking is fundamentally solved by changing the situation of real estate economy by making use of e-commerce. As a result, the sound and cyclic development of real estate fund is realized. The development of e-commerce model facilitates the activity efficiency of real estate in the field of e-commerce. Through application of e-commerce, the problem about real estate destocking can be solved effectively [12]. Besides, the stock of commercial houses and office buildings can be activated by expediting ABS pilot of housing including REITS [3]. Exerting great efforts to implement shantytown transformation and monetary resettlement is also the main way to facilitate destocking of commercial houses [13].

\subsection{Implementing Differentiated Real Estate Control Policies}

The hot real estate in first-tier and second-tier cities and depressed real estate in the third-tier and lower-tier cities have promoted China's real estate policy to implement differentiated regulation. In third-tier and lower-tier cities, civilization progress of migrant workers should be sped up to expand housing demand. Meanwhile, reconstruction of shanty towns and construction of indemnificatory housing should also be sped up. Deepening the reform of housing system and adhering to buying and rent, the government requires real estate enterprises to 
lower sales prices, especially for the high house prices regions. Housing policies beneficial to the consumer can be issued in these regions to make local government, real estate development enterprises and housing investors for interest concessions, so as to really achieve the destocking [14]. The government should encourage developers to conform to market laws to appropriately lower price, it can also speed up the destocking process through necessary encouragement measures, such as subsidy [15]. As for the first-tier and second-tier cities, as well as the cities where housing price increases highly and rapidly, corresponding means should be taken to restrain the "land speculation" of local governments and "housing speculation" of venture capital. Through the supply side reform, opportunities will be provided for the transformation and innovation to the real estate enterprises, so as to enable them relief, more involve in deepening the housing system reform. The differentiation of real estate market in current stage should be treated differently. Firstly, the real situation needs to be found out and inventory data should be checked, so as to find the basic reasons for the formation of inventory, and make an antidote against the disease [9]. Only by following the requirements of the central to implement differentiated regulation and control policy can the real estate inventory be digested orderly.

\section{Conclusion}

Real estate destocking is a complicated process, during which the opportunities and challenges coexist. To effectively and orderly realize destocking, it is necessary for the government to carry out macroscopic regulation, issue guiding policies and build partnership with developers, financial institutions, investors and the media. In this way, the initial achievement in orderly destocking could be fulfilled in the coming 2 - 4 years. Additionally, the strategies such as reform in supply, destocking acceleration and economic growth stabilization could be implemented.

\section{References}

[1] Real Estate Destocking: Do or Not Do. Shanghai Securities News, 2016-1-21.

[2] Zhang, K. (2016) Research Group of CASS: The Housing Price Might Comprehensive Decline in the Second Half of 2017. http://www.yicai.com/news/5009941.html

[3] Shao, T. (2016) Implement Multiple Measures Spontaneously and Alleviate the Pressure over Real Estate "Destocking" Positively. Development Research, 5, 4-6.

[4] Yi, X.R. (2016) Difficulties and Emphases of Real Estate Destocking. Zhejiang Economy, 3, 12-15.

[5] Ge, F. (2015) Real Estate Destocking: More Opportunity Than Challenges. China Economic Weekly, $46,31$.

[6] Zhou, C. (2014) China Real Estate Suffers from "Population Trap”: Or Perhaps Taking the Steps of Collapse in Japanese. http://business.sohu.com/20141209/n406789485.shtml

[7] Chen, H.Y. (2016) Reflections about Real Estate Destocking and Financial Risk. Science \& Technology Economy Market, 4, 166.

[8] Ma, G.Y. (2016) “Authority” Determines the Keynote of Governmental Real Estate Destocking. http://finance.eastmoney.com/news/1365,20160510622545483.html

[9] Shi, K. (2015) Method for Real Estate Destocking-Solving Real Estate Stocking. New Finance, 12, 54-55.

[10] Wang, R.H. (2016) Fight the "Battle” of Real Estate Destocking. Shanghai Real Estate, 3, 12-13.

[11] Ren, Z.P. (2016) Along with the Gradually Lost Population Dividend, the Long-Term Period Turning Point of Real Estate Is Coming. http://finance.sina.com.cn/china/gncj/2016-05-19/doc-ifxsktkp8950990.shtml

[12] Wang, J. (2015) Analysis and Study of Influences of E-Commerce Development on Real Estate Destocking. Engineering Economy, 4, 106-110.

[13] Li, W.T. (2016) Study on Real Estate Destocking under the Background of Supply Reform. Market Economy \& Price, 6, $18-20$.

[14] Yi, X.R. (2016) Real Estate Destocking Is the Adjustment of Vital Interest Relationship. Invest Beijing, 1, 42-43.

[15] Xuan, Y. (2016) Thoughts about Real Estate Destocking. China Development Observation, 8, 28-30. 


\section{Submit or recommend next manuscript to SCIRP and we will provide best service for you:}

Accepting pre-submission inquiries through Email, Facebook, LinkedIn, Twitter, etc.

A wide selection of journals (inclusive of 9 subjects, more than 200 journals)

Providing 24-hour high-quality service

User-friendly online submission system

Fair and swift peer-review system

Efficient typesetting and proofreading procedure

Display of the result of downloads and visits, as well as the number of cited articles

Maximum dissemination of your research work

Submit your manuscript at: http://papersubmission.scirp.org/ 